\title{
The Current Account, the Spot Exchange Rate and the Demand for Money
}

\author{
Anthony Joseph \\ Department of Computer Science
}

Seidenberg School of Computer Science and Information Systems, Pace University

163 William Street, New York, NY 10038, USA

Tel: 1-212-346-1492Ｅ-mail: ajoseph2@pace.edu

\author{
Maurice Larrain \\ Department of Finance and Economics \\ Lubin School of Business, Pace University \\ One Pace Plaza, New York, NY 10038, USA
}

Tel: 1-212-618-6521Ｅ-mail: mlarrain@pace.edu

\author{
Richard Ebil Ottoo (Corresponding author) \\ Department of Finance and Economics \\ Lubin School of Business, Pace University \\ One Pace Plaza, New York, NY 10038, USA
}

Tel: 1-212-618-6526 E-mail: rottoo@pace.edu

Received: December 21, 2011

doi:10.5539/ijef.v4n3p13

\author{
Accepted: January 12, $2012 \quad$ Published: March 1, 2012 \\ URL: http://dx.doi.org/10.5539/ijef.v4n3p13
}

\begin{abstract}
We derive a theoretical balance of payments current account model from a framework that assumes a monetary model of exchange rates as a first state of the world, but then presumes the existence of deviations from purchasing power parity. In such a model there is slow price adjustment where short-run exchange rates deviate from long-run equilibrium exchange rates. Under these conditions there are accumulations of net foreign assets due to current account imbalances. A nonlinear model results where there is dependence between exchange rate deviations from equilibrium and the current account, as well as a concurrent dependence of the current account on exchange rate deviations. Furthermore, the current account is also shown to depend on the demand for money. Thus the theoretical explanation of the current account is concomitant on the short-run exchange rate and the determinants of money demand.
\end{abstract}

Keywords: Current account, Net foreign assets, Exchange rate deviation, Nonlinear monetary model, Money demand

JEL Classification: E41; F31; F32.

\section{Current Account Analysis}

Current account analysis has progressed from the elasticities and absorption approaches to the Mundell-Fleming framework, then to the Monetary, Intertemporal and Portfolio approaches. Our brief summary below will discuss the monetary model last, since it is used as a platform on which we build our own model. Current account models can be said to have begun with the trade analytics of elasticities and absorption approaches, followed by the expanded scope of the Mundell-Fleming model which included international capital flows and allowed monetary and fiscal policy analysis. Improving on both the short-term horizon and depth of the Mundell-Fleming model, the intertemporal approach assumes that the behavior of the current account reflects the intertemporal choices of economic agents. Basically the current account depends on intertemporal consumption which determines savings, and on the world-wide equality of the marginal product of capital which determines investment. 


\subsection{The Intertemporal Approach}

Intertemporal models focus on expected discounted changes in net output which are dependent on the long-run saving and investment decisions of economic agents. The approach considers optimizing economic agents with forward looking decision rules, where international borrowing and lending are used to finance intertemporal substitution that enables consumption smoothing. The ultimate determinant of the current account is the savings-investment gap: countries with higher savings will experience current account surpluses, and countries with lower savings will have deficits and import capital. Intertemporal models have solid microeconomic foundations which Ju and Wei (2007) assert can be connected to Friedman's permanent income hypothesis. Going beyond the workhorse single risk-free security models, many of them featured in Obstfeld and Rogoff's (2002) survey, there are also multiple security models. These are known as complete market models and use the Arrow-Debreau securities construct to incorporate a full variety of financial instruments such as stocks, bonds, derivatives and other securities. As Knight and Scacciavillani (1998) point out, an advantage of the Arrow-Debreau framework is that consumption smoothing can be done both between time periods as well as states of the world.

\subsection{Portfolio-Balance Models}

Compared to the forward looking optimizing agent intertemporal approach, portfolio balance theory posits that the capital flows of the current account are the consequence of portfolio decisions reflecting the demand for portfolio assets. In a study evaluating a variety of portfolio models Guo and Jin (2009) develop a non-structural accounting framework of the current account. This framework breaks down the current account into two basic components: a composition effect and a growth effect. An overview of this framework provides a good description of the new portfolio balance approach to the current account. Consider:

$$
w_{T}=w_{D}+A
$$

Where $\left(w_{T}\right)$ is total wealth, $\left(w_{D}\right)$ is the domestic capital stock and $A$ are net foreign assets which are defined as

$$
A=\theta w_{T}
$$

where $(\theta)$ is the share of net foreign assets $(A)$ in total wealth. The differentiation of Equation (2) results in

$$
\Delta A=a=\Delta \theta w_{T}+\theta \Delta w_{T}
$$

$\Delta A$ is the change in net foreign assets. $\Delta A$ is also by definition the current account of the balance of payments which we now label $(a) . \Delta \theta$ is the change in the foreign asset's share of the wealth portfolio; and $\left(\Delta w_{T}\right)$ depicts the change in total wealth. Finally $\left(\Delta w_{T}\right)$ is period savings $(S)$. Thus we can write:

$$
a=\Delta \theta w_{T}+\theta S
$$

where the current account $(a)$ is the consequence of two effects: the composition or reallocation effect shown by the term $\left(\Delta \theta w_{T}\right)$, and the portfolio growth effect represented by the term $(\theta S)$. The research arguments then center on whether the composition effect does or does not outweigh the growth effect, or whether both are relevant forces in current account determination. This framework accommodates models developed by Kray and Ventura (2000, 2003), Lane and Milesi-Ferreti (2006) and Gourinchas and Rey (2007), among others.

\subsection{The Monetary Model of the Current Account}

The monetary model (MM) assumes purchasing power parity (PPP) holds, that money demand is stable, and that there exists flexible wages and prices. The (MM) is a long-run equilibrium model that can be applied to both fixed and floating exchange rate regimes. The applications are similar in that the changes in money demand and supply that bring about current account surpluses and deficits under fixed exchange rates are very much the same forces that bring about currency appreciations and depreciations under floating exchange rates. A detailed analysis of the fundamentals of the current account model is found in Humphrey (1981), who describes that at its most basic -when actual cash balances diverge from desired balances and there is current account disequilibria -- the (MM) assumes agents will adjust this divergence. They do so by changing the exports/imports of domestic goods and securities for imports/exports of money, with international reserves flowing to restore monetary equilibrium in the balance of payments. Kemp (1975) submits the (MM) model treats the transactions in the balance of payments as reflecting aggregate portfolio decisions by domestic and foreign agents, but acknowledges the adjustment behavior is incomplete in the short-run as it takes time for actual money balances to reach their desired level.

For the purposes of this paper, however, it will be shown that the true value of the monetary approach lies much more in the monetary exchange rate model than in the monetary current account model. This is because we use the (MM) exchange rate model in the following section as a platform from which we derive a new behavioral relationship to describe changes in net foreign assets. That is, we transform the exchange rate model into a far more 
flexible and richer current account approach than the original monetary model of the current account. We therefore begin our modeling process by briefly describing the fundamentals of the monetary exchange rate model below.

\subsection{The Monetary Model of Exchange Rates}

Two different formulations of the (MM) have been used in the literature. One derives the (MM) from the quantity theory of money, where the exchange rate is made dependent on relative money supplies, velocities and real incomes. A second version substitutes relative velocities with relative interest rates. Empirical studies have used both forms, though Dornbusch (1980), among others, shows the velocity model easily converts into the more widely used interest rate version. There could be some modern relevance, however, to the velocity approach as Sargent and Surico (2011), referencing Luca's (1980) article, point out that developments over 2007-2010 have reignited interest in the quantity theory of money, due to the strong growth in the balance sheets of central banks.

The basic version of the monetary model assumes prices are flexible and that purchasing power parity holds. The long-run exchange rate, $\left(e^{*}\right)$ is a function of the relative prices of any two countries $(i)$ and $(j)$. Expressed in natural logarithms we have

$$
e_{i j}^{*}=p_{i}-p_{j}
$$

The money demand functions are identical in both countries and are:

$$
\begin{aligned}
& m_{i}=p_{i}+\alpha y_{i}-\delta r_{i} \\
& m_{j}=p_{j}+\alpha y_{j}-\delta r_{j}
\end{aligned}
$$

Where $(m)$ is nominal money, $(p)$ is the price level, $(y)$ is real income, $(r)$ is the nominal interest rate, and $(\alpha)$ and $(\delta)$ represent parameters. From (5), (6) and (7) we can write:

$$
e_{i j}^{*}=p_{i}-p_{j}=\left(m_{i}-m_{j}\right)-\alpha\left(y_{i}-y_{j}\right)+\delta\left(r_{i}-r_{j}\right)
$$

Thus the long-run exchange rate $\left(e^{*}\right)$ depends on relative money supplies, real incomes and nominal interest rates. The MM approach also assumes that local and foreign bonds are perfect substitutes, so that uncovered interest rate parity holds. In this case bond supplies do not affect either exchange or interest rates. If perfect substitutability is relaxed as an assumption interest rate parity would no longer be in effect. Since a premium is now required on foreign assets, a portfolio approach would then appear to be more appropriate, and the exchange rate would now also depend on relative supplies of domestic and foreign bonds. Therefore the degree of asset substitutability and the degree of usefulness of the monetary model appear to be inversely related.

Tests of the MM have largely used consumer price indices as surrogates for PPP measures. The empirical outcomes have been controversial, with results reported as poor from the 1970's to the mid 1990's, to statistically acceptable in the recent past and present. Mostly negative results have been reported in a comprehensive survey by Rogoff (1996). More recent research by Chowdry et al (2005) contends Rogoff's surveyed literature has used inadequate PPP measures, and criticizes the widespread use of the CPI in computing PPP. Chowdry's contribution is to replace the CPI with a price measure extracted from nominal equity returns, since this new measure is found to be a better proxy for unobservable pure price inflation. Subsequent empirical tests show the recalculated PPP and exchange rate differentials to be of the same order of magnitude, thus lending strong support to the MM. A variety of other recent work also finds empirical validity for the monetary model and is referenced in Larrain (2003).

\section{Developing a Current Account Model from the Monetary Exchange Rate Model}

\subsection{Modifying the MM's Money Demand Function}

In addition to its use of CPI measures, some of the failings of the monetary model have also been attributed to its use of a simplistic money demand function. For example Dornbusch (1980) acknowledges that the demand for money in the versions of the traditional monetary model employed by Mussa (1976), Frenkel (1976), Bilson (1978) and Hodrick (1978) is poorly specified, since it does not include adjustment lags or long-term interest rates to measure the alternative cost of holding money as compared to long term assets. By modifying the money demand function Dornbusch (1980) obtains substantial improvement in statistical testing. Wilson's (2009) modifications go further, in that the demand for money is also assumed to be a function of future income and interest rates and of the risk associated with holding domestic currency. Wilson (2009) uses the money demand equation developed by Kia (2006) where, among other variables, the risk associated with holding domestic currency is also made a function of (i) government deficits as a share of GDP; (ii) total government debt as a share of GDP; and (iii) foreign financed debt as a share of GDP. Tests of this expanded money demand function also provide empirical support for the monetary model. Other variables incorporated into money demand functions include earnings projections which would reveal changes in the perceived opportunity cost of holding money (Carpenter and Lange, 2002); 
unemployment which can represent precautionary demand (De Bondt, 2009); and returns on stocks and bonds (Mankiw, 2003).

We also consider the MM's money demand function to be limited in scope and assume a slightly more complex demand structure which follows Ericsson's (1998) commonly used money demand specification. This results in the functional relationship shown below

$$
m-p=\alpha y+\beta_{1} w_{D}+\beta_{2} \theta w_{T}-\gamma R-\delta r-\epsilon \pi
$$

where $(m-p)$ is real money, $(y)$ is real income, and $(\alpha),(\beta),(\gamma),(\delta)$, and $(\epsilon)$ are parameters. The wealth term $(w)$ is decomposed here into a domestic component $\left(w_{D}\right)$ and a foreign component $\left(\theta w_{T}\right)$, where $(\theta)$ is the share of net foreign assets $(A)$ in total wealth. The $\left(\theta w_{T}\right)$ term in equation (9) can be recognized as the same net foreign assets term differentiated by Guo and Jin (2009) to obtain the composition and growth components of the portfolio current account approach. The opportunity costs of holding money are $(R),(r)$ and $(\pi)$, which represent long and short term nominal interest rates and the inflation rate, respectively. These opportunity costs are in theory negatively related to narrowly defined real money. However, for broader measures such as M2 and M3, Fase and Winder (1998) maintain that while $(R)$ would still be negatively related, a positive relationship to $(r)$ is plausible.

Substituting the money demand function of equation (9) for countries ( $i$ and $j$ ) into Equation (5) the resulting long-run exchange rate is now:

$$
e_{i j}^{*}=p_{i}-p_{j}=m_{i j}-\alpha y_{i j}+\beta_{1} w_{D i j}+\beta_{2} \theta w_{T i j}+\gamma R_{i j}+\delta r_{i j}+\epsilon \pi_{i j}
$$

where terms for the independent variables represented in the form $\left(x_{i j}\right)$ indicate an abbreviation for $\left(x_{i}-x_{j}\right)$.

\subsection{A Model of the Current Account under PPP Deviations}

Under freely floating purchasing power parity long-run equilibrium exchange rates $\left(e^{*}\right)$, product and asset markets are in equilibrium, and there is perfect capital mobility. Consequently there would be no deficits or surpluses on the current/capital accounts. However, a balance of payments disequilibrium will be experienced if market imperfections become present and lead to a short-run non-equilibrium exchange rate $(e)$ such that there is a nonzero deviation $\left(e-e^{*}\right)$. Given a nonlinear response by changes in net foreign assets $(a)$ to this discrepancy a joint interaction between the current account and exchange rates can be explicitly developed. To derive this relationship we utilize the same set of nonlinear functions used by Larrain (2003) in analyzing central bank intervention parameters. We differ however in (i) that the degree of reversion towards equilibrium need not increase with the size of the deviation from PPP, (ii) our more complex definition of the money demand function, and (iii) our focus on the current account instead of market intervention by the monetary authorities.

Assume that goods prices are slow to adjust, such that there exists a deviation of a short-run exchange rate $(e)$ from the long-run equilibrium PPP exchange rate $\left(e^{*}\right)$. There would then be an accumulation of net foreign assets through a current account imbalance $(a)$. Furthermore we assume this imbalance is represented by the nonlinear function

$$
a_{i j}=\varphi\left(e_{i j}-e_{i j}^{*}\right)^{v}
$$

where $(\varphi)$ is a parameter and $(v)$ is an exponent.

Although it is at times presumed that a return to equilibrium is rapid, it is also plausible to consider that deviations from PPP as shown above may be long lasting. In an extension to international pricing models by Krugman (1987) and Dornbusch $(1976,1987)$, a recent study by Atkeson and Burstein (2008) shows persistent deviations from PPP can come about from firms pricing-to-market in an environment of persistent changes in the relative cost of production across countries.

Dividing (11) by $(\varphi)$ we have (see Mathematical Appendix for detailed steps):

$$
\frac{a_{i j}}{\varphi}=\left(e_{i j}-e_{i j}^{*}\right)^{v}
$$

from where

$$
e_{i j}-e_{i j}^{*}=\frac{\left(a_{i j}\right)^{1 / v}}{\varphi^{1 / v}}=\varphi^{-1 / v}\left(a_{i j}\right)^{1 / v}
$$

and

$$
e_{i j}=e_{i j}^{*}+\varphi^{-1 / v}\left(a_{i j}\right)^{1 / v}
$$


Further rearrangements yield

$$
\begin{aligned}
\left(a_{i j}\right)^{1 / v}= & \varphi^{1 / v} e_{i j}-\varphi^{1 / v} m_{i j}+\left(\varphi^{1 / v} \alpha\right) y_{i j}+\left(\varphi^{1 / v} \beta_{1}\right) w_{D_{i j}}+ \\
& +\left(\varphi^{1 / v} \beta_{2}\right) \theta w_{T_{i j}}-\left(\varphi^{1 / v} \gamma\right) R_{i j}-\left(\varphi^{1 / v} \delta\right) r_{i j}-\left(\varphi^{1 / v} \epsilon\right) \pi_{i j}
\end{aligned}
$$

Thus the short-run exchange rate $\left(e_{i j}\right)$ is shown in Equation (14) to depend on the current account as well as the long run purchasing power parity exchange rate. In turn, Equation (15) shows the current account to depend on the short-run exchange rate as well as the variables defined above as determinants of prices in the money demand functions, as represented by $\left(e_{i j}{ }^{*}\right)$ and discussed in Equations (9) and (10) above.

Equation (15) can be expressed more simply. Since $\varphi, \alpha, \beta, \delta, \epsilon$ are parameters, let $\alpha_{0}=\varphi^{1 / v}, \alpha_{1}=\left(\varphi^{1 / v} \alpha\right), \alpha_{2}=$ $\left(\varphi^{1 / v} \beta_{1}\right), \alpha_{3}=\left(\varphi^{1 / v} \beta_{2}\right), \alpha_{4}=\left(\varphi^{1 / v} \gamma\right), \alpha_{5}\left(\varphi^{1 / v} \delta\right)$, and $\alpha_{6}=\left(\varphi^{1 / v} \epsilon\right)$ So we can write:

$$
\left(a_{i j}\right)^{1 / v}=\alpha_{0}\left(e_{i j}-m_{i j}\right)+\alpha_{1} y_{i j}+\alpha_{2} w_{D_{i j}}+\alpha_{3} \theta w_{T_{i j}}-\alpha_{4} R_{i j}-\alpha_{5} r_{i j}-\alpha_{6} \pi_{i j}
$$

In Equation (16), the current account depends on relative short-term exchange rates $\left(e_{i j}\right)$, nominal money supplies $\left(m_{i j}\right)$, real income $\left(y_{i j}\right)$, domestic wealth $\left(w_{D i j}\right)$, the stock of net foreign assets $\left(\theta w_{T i j}\right)$, long and short-term interest rates $\left(R_{i j}\right)$ and $\left(r_{i j}\right)$, and inflationary expectations $\left(\pi_{i j}\right)$. When the variables of Equation (16) are interpreted as growth rates instead of levels, the first right-hand side term normalizes the growth in the exchange rate by the growth in the relative money supplies.

\section{Characteristics of the Deviation Models}

There are several features to the current account deviation model. (i) It is a short-run horizon model; (ii) it is a nonlinear construct based on imperfect market adjustments; (iii) there is interdependence between the current account and short-run exchange rates and vice versa; (iv) the current account is a direct function of the short-run exchange rate and the determinants of money demand; (v) the model is amenable to policy analysis.

Our current account model is derived from a nonlinear iterative system which in generic form can be described by two general functions as shown in Equations (17) and (18)

$$
a=h\left(e, e^{*}\right)
$$

and

$$
e=f\left(a, e^{*}\right)
$$

The current account relationships are based on deviations from purchasing power parity within the framework of a monetary model of exchange rates. In this model short-run exchange rates deviate from long-run equilibrium exchange rates because of slow price adjustment. Under these conditions there are accumulations of net foreign assets due to current account imbalances. We have shown that there is a joint interdependence between exchange rate deviations and the current account, as well as a concurrent dependence of the current account on exchange rate deviations. That is, the current account is a function of the deviation of short-run rates from their long-run equilibrium, and in turn, deviations of short-run rates depend on the existence of a nonzero current account. From this premise we derive a behavioral equation for the current account. This behavior is related to the desire for holding money as compared to other assets. A relevant point is that the current account in equation (17) is shown to depend directly, among other variables, on the short-run exchange rate. In comparison neither the intertemporal nor the portfolio models have been designed to assign a direct role to the exchange rate, nor is their construct intended to consider the possibility of feedbacks between exchange rates and the current account.

Exchange rates are of consequence for a short-run model because they generate two effects in the international adjustment process. One effect is through (i) a trade-weighted exchange rate influencing net exports. This is the type of exchange rate our model is designed to cope with. The other effect comes from (ii) a financially weighted exchange rate operating through a valuation channel which impacts capital gains and losses. The valuation effect depends on the size and currency composition of foreign assets and liabilities. Lane and Shambaugh (2010) point out its quantitative significance has developed markedly in importance over the past decade with the rapid growth of international financial holdings among countries. They further suggest modeling the dual role of exchange rates in analyzing international adjustment, and our model could be so adapted. Since their research has found substantial 
heterogeneity in the co-movement of these two rates it is likely the addition of a financial exchange rate should not present statistical issues in future testing.

In this deviation model, the direct determinants of the current account/net foreign assets, in addition to the short-run exchange rate, are the determinants of the money demand function. We cannot a priori state that the Ericcson (1998) money demand function used in this study is the "appropriate" demand function to be used in current account analysis. This is both a theoretical and an empirical question beyond the scope of the present paper. As discussed above, at least eight additional economic variables beyond Ericsson's seven basic choices shown in Equation (9) have been used in specifying money demand functions. The purpose of this paper, however, is not to favor a specific demand function. It is instead to point out the analytical usefulness of a monetary approach to current account analysis.

The research on money demand is ongoing, extensive, deep, rich, and has a long and intellectually rewarding history. This indicates that the nature and number of the constituent variables in explaining the current account in future deviation models will be linked to the degree of theoretical sophistication and empirical stability of the statistical results of modern research on money demand functions. This paper points to the fact that the powerful analytical tradition and insights of monetary research can be used as a tool which may in turn bring additional perspectives to the analysis of the current account/net foreign assets of the international balance of payments.

\section{Conclusion}

This paper extends the basic monetary model of exchange rates into a nonlinear model of the current account under imperfect capital mobility and slow price adjustment. In our extended current account model short-run exchange rates are assumed to deviate from long-run purchasing power exchange rates and this divergence generates accumulations of net foreign assets through current account imbalances. These imbalances in turn affect exchange rates, so the model shows a two-way causality, whereby exchange rates influence the current account which then helps determine exchange rates. In comparison neither the intertemporal nor the portfolio models of the current account assign a direct role to the exchange rate. Of equal import, the current account is also shown to depend on the demand for money and therefore on the variables that determine this demand. The study of money demand is well established and the literature has a rich variety of sophisticated models which have undergone empirical tests and could be used in advancing the type of model presented in this paper. The approach of the deviation model to current account determination is relatively straightforward and behavioral. It simply states the current account depends on movements in short-run exchange rates and the desire to hold cash balances. This compares with the more complex analytical structure and empirical difficulties of the intertemporal approach, as well as the accounting framework of the portfolio models.

\section{References}

Atkeson, A., \& Burstein, A. (2008). Pricing to Market, Trade Costs and International Relative Prices. American Economic Review, 98(5). 1998-2031. http://dx.doi.org/10.1257/aer.98.5.1998

Bilson, J. (1978). The Monetary Approach to the Exchange Rate - Some Empirical Evidence. IMF Staff Papers, 25 (March). 48-75.

Carpenter, S., \& Lange, J. (2002). Money Demand and Equity Markets. FEDS Working Paper, No. 2003-03.

Chowdhry, B., Roll, R., \& Xia, Y. (2005). Extracting Inflation from Stock Returns to Test Purchasing Power Parity. American Economic Review, 95(1). 255-276. http://dx.doi.org/10.1257/0002828053828554

De Bondt, G. (2009). Euro Area Money Demand Empirical Evidence on the Role of Equity and Labor Markets. European Central Bank Working Paper Series. No. 1086 (September).

Dornbusch, R. (1976). Expectations and Exchange Rate Dynamics. The Journal of Political Economy, 84(6). 1161-1176. http://dx.doi.org/10.1086/260506

Dornbusch, R. (1980). Monetary Policy under Exchange Rate Flexibility. National Bureau of Economic Research Working Paper, No. 0311. Cambridge: Massachusetts.

Dornbusch, R. (1987). Exchange Rates and Prices. American Economic Review, 77(1). 93-106.

Ericsson, N. R. (1998). Empirical Modeling of Money Demand. Empirical Economics, 23. 295-315. http://dx.doi.org/10.1007/BF01294409

Fase, M., \& Winder, C. (1998). Wealth and the Demand for Money in the European Union. Empirical Economics, 23. 507-524. http://dx.doi.org/10.1007/BF01294420 
Frenkel, J. (1976). A Monetary Approach to the Exchange Rate: Doctrinal Aspects and Empirical Evidence. Scandinavian Journal of Economics, 76 (May). 200-224. http://dx.doi.org/10.2307/3439924

Guo, K., \& Jin, K. (2009). Composition and Growth Effects of the Current Account: A Synthesized Portfolio View. Journal of International Economics, 79. 31-41. http://dx.doi.org/10.1016/j.jinteco.2009.03.003

Gourinchas, P., \& Rey, H. (2007). International Financial Adjustment. Journal of Political Economy, 115. 665-703. http://dx.doi.org/10.1086/521966

Hodrick, R. (1978). An Empirical Analysis of the Monetary Approach to the Determination of the Exchange Rate. In J. Frenkel, \& H.G. Johnson, (eds.) The Economics of Exchange Rates. Addison Wesley.

Humphrey, T. (1981). Adam Smith and the Monetary Approach to the Balance of Payments. Economic Review, Federal Reserve Bank of Richmond. 3-10.

Ju, J., \& Wei, S. (2007). Current Account Adjustment: Some New Theory and Evidence National Bureau of Economic Research Working Paper. No. 13388. Cambridge: Massachusetts.

Kemp, D. (1975). A Monetary View of the Balance of Payments. Federal Reserve Bank of St. Louis, (April). 14-22.

Kia, A. (2006). Monetary Policy and Inflation in Developing Countries: Internal or External Factors? Evidence from Iran. Journal of Asian Economics, 17. 879-903. http://dx.doi.org/10.1016/j.asieco.2006.08.011.

Knight, M., \& Scacciavillani, F. (1998). Current Accounts: What is Their Relevance for Policymaking? IMF Working Paper. WP/98/71.

Kraay, A., \& Ventura, J. (2000). Current Accounts in Debtor and Creditor Countries. Quarterly Journal of Economics, 115. 1137-1166. http://dx.doi.org/10.1162/003355300555033.

Kraay, A., \& Ventura, J. (2003). Current Accounts in the Long and Short Run. In Gertler, M. \& Rogoff, K. (eds.). NBER Macroeconomics Annual, Cambridge, Massachusetts: MIT Press.

Krugman, P. (1987). Pricing to Market When the Exchange Rate Changes. In Sven W. Arndt \& J. David Richardson (eds.). Real-Financial Linkages Among Open Economies. Cambridge, Massachusetts: MIT Press, (49-70).

Lane, P., \& Milesi-Ferreti, G. (2006). A Global Perspective on External Positions. In Clarida, R. (ed.). G7 Current Account Imbalances: Sustainability and Adjustment. Chicago: Chicago University Press, (67-98).

Lane, P., \& Shambaugh, J.C. (2010). Financial Exchange Rates and International Currency Exposures. American Economic Review, 100(1). 518-540. http://dx.doi.org/10.1257/aer.100.1.518.

Larrain, M. (2003). Central Bank Intervention, the Current Account, and Exchange Rates. International Advances in Economic Research, 9(3). 196-205. http://dx.doi.org/10.1007/BF02295443.

Lucas, R. E. (1980). Two Illustrations of the Quantity Theory of Money. American Economic Review, 70(5). 1005-14.

Mankiw, G. N. (2003). Macroeconomics, (5 ${ }^{\text {th }}$ ed.). Worth, (591).

Mussa, M. (1976). The Exchange Rate, The Balance of Payments, and Monetary and Fiscal Policy Under a Regime of Controlled Floating. Scandinavian Journal of Economics, 78 (May). 229-248.

Obstfeld, M., \& Rogoff, K. (2002). Foundations of International Macroeconomics. (5 ${ }^{\text {th }}$ ed.). Cambridge, Massachusetts: MIT Press.

Rogoff, K. (1996). The Purchasing Power Parity Puzzle. Journal of Economic Literature, 34(2). 647-668.

Sargent, T. J., \& Surico, P. (2011). Two Illustrations of the Quantity Theory of Money: Breakdowns and Revivals. American Economic Review, 101(1). 109-28. http://dx.doi.org/10.1257/aer.101.1.109.

Wilson, I. (2009). The Monetary Approach to Exchange Rates: A Brief Review and Empirical Investigation of Debt, Deficit, and Debt Management - Evidence from the United States. The Journal of Business Inquiry. 8(1). 83-99.

\section{Mathematical Appendix}

This appendix shows the steps beginning in Equation (11) and ending in Equation (16) that were not shown in the development of the mathematical argument of Section 2.2 of this paper. Equation (1) in this appendix corresponds to Equation (11) in the text.

A current account imbalance is represented by the nonlinear function shown in Equation (1).

$$
a_{i j}=\varphi\left(e_{i j}-e_{i j}^{*}\right)^{v}
$$


Dividing Equation (1) by $(\varphi)$, we have

$$
\frac{a_{i j}}{\varphi}=\left(e_{i j}-e_{i j}^{*}\right)^{v}
$$

Raising to the power of $(1 / v)$ leads to

$$
\begin{gathered}
\left(\frac{a_{i j}}{\varphi}\right)^{1 / v}=e_{i j}-e_{i j}^{*} \\
e_{i j}-e_{i j}^{*}=\frac{\left(a_{i j}\right)^{1 / v}}{\varphi^{1 / v}}=\varphi^{-1 / v}\left(a_{i j}\right)^{1 / v}
\end{gathered}
$$

Equation (4) shows the exchange rate deviation to be dependent on the current account. The current account is now expressed as

$$
\begin{aligned}
& \left(a_{i j}\right)^{1 / v}=\varphi^{1 / v}\left(e_{i j}-e_{i j}^{*}\right) \\
& \left(a_{i j}\right)^{1 / v}=\varphi^{1 / v} e_{i j}-\varphi^{1 / v} e_{i j}^{*}
\end{aligned}
$$

Since $e_{i j}^{*}$ is defined as $\left(\mathrm{p}_{\mathrm{i}}-\mathrm{p}_{\mathrm{j}}\right)$ we now substitute the determinants of $\mathrm{p}_{\mathrm{i}}$ and $\mathrm{p}_{\mathrm{j}}$ from our money demand function into Equation (6) to obtain

$$
\left(a_{i j}\right)^{1 / v}=\varphi^{1 / v} e_{i j}-\varphi^{1 / v}\left[m_{i j}-\alpha y_{i j}-\beta_{1} w_{D_{i j}}-\beta_{2} \theta w_{T_{i j}}+\gamma R_{i j}+\delta r_{i j}+\epsilon \pi_{i j}\right]
$$

From which

$$
\begin{aligned}
\left(a_{i j}\right)^{1 / v}=\varphi^{1 / v} e_{i j}- & \varphi^{1 / v} m_{i j}+\left(\varphi^{1 / v} \alpha\right) y_{i j}+\left(\varphi^{1 / v} \beta_{1}\right) w_{D_{i j}}+\left(\varphi^{1 / v} \beta_{2}\right) \theta w_{T_{i j}}- \\
& -\left(\varphi^{1 / v} \gamma\right) R_{i j}-\left(\varphi^{1 / v} \delta\right) r_{i j}-\left(\varphi^{1 / v} \epsilon\right) \pi_{i j}
\end{aligned}
$$

Since $\varphi, \alpha, \beta, \gamma, \delta, \epsilon$ are parameters, let $\alpha_{0}=\varphi^{1 / v}, \alpha_{1}=\left(\varphi^{1 / v} \alpha\right), \alpha_{2}=\left(\varphi^{1 / v} \beta_{1}\right), \alpha_{3}=\left(\varphi^{1 / v} \beta_{2}\right), \alpha_{4}=$ $\left(\varphi^{1 / v} \gamma\right), \alpha_{5}=\left(\varphi^{1 / v} \delta\right)$, and $\alpha_{6}=\left(\varphi^{1 / v} \epsilon\right)$ so that we can rewrite (8) more simply as

$$
\left(a_{i j}\right)^{1 / v}=\alpha_{0}\left(e_{i j}-m_{i j}\right)+\alpha_{1} y_{i j}+\alpha_{2} w_{D_{i j}}+\alpha_{3} \theta w_{T i j}-\alpha_{4} R_{i j}-\alpha_{5} r_{i j}-\alpha_{6} \pi_{i j}
$$

where the short-run exchange rate is normalized by the demand for money. Equation (9) can also be expressed as

$$
a_{i j}=\left[\alpha_{0}\left(e_{i j}-m_{i j}\right)+\alpha_{1} y_{i j}+\alpha_{2} w_{D_{i j}}+\alpha_{3} \theta w_{T i j}-\alpha_{4} R_{i j}-\alpha_{5} r_{i j}-\alpha_{6} \pi_{i j}\right]^{v}
$$

